\title{
IMPACT OF HIGH TEMPERATURE AND OTHER FACTORS ON PV MODULE EFFICIENCY ON SMALL FARMS IN LATVIA
}

\author{
Normunds Stanka, Aivars Aboltins, Janis Palabinskis \\ Latvia University of Life Sciences and Technologies, Latvia \\ normunds.stanka@inbox.lv, aivars.aboltins@inbox.lv, janis.palabinskis@1lu.lv
}

\begin{abstract}
Conversion of light into electricity is a relatively new invention. The use of solar energy has grown rapidly in the world. Advances in technology, climate change and price reduction have made PV systems very popular nowadays. However, despite the huge advances in technology, PV modules have relatively low efficiency. It is very important, because it shows how much solar energy PV modules can convert into electrical power. There are many factors that affect the efficiency of PV modules. One of them is temperature. It may seem a surprise for many people, but PV module performance is affected negatively by temperature increases. Therefore, it is important to examine the power losses of PV module overheating. The aim of this study is to determine and compare power losses from PV module overheating in several days with different weather conditions. Within this study 4 different days with various weather conditions were selected. For each day measurements of solar irradiance, solar elevation angle, solar azimuth angle, ambient temperature, PV module temperature and PV power from sunrise to sunset were obtained. The time of sunrise and sunset were different on each day. In order to achieve more objective results, the obtained data were analysed from 10:00 to 18:00. The ranges of average results in the given time period were determined and compared. The average solar irradiance ranged from 432.74 to $665.37 \mathrm{~W} \cdot \mathrm{m}^{-2}$, average ambient temperature from 13.50 to $25.35^{\circ} \mathrm{C}$, average $\mathrm{PV}$ module temperature from 27.03 to $43.07^{\circ} \mathrm{C}$, average $\mathrm{PV}$ power from 77.13 to $122.51 \mathrm{~W} \cdot \mathrm{m}^{-2}$, average power losses from PV module overheating from 0.81 to $7.23 \%$ (from 1.25 to $7.98 \mathrm{~W} \cdot \mathrm{m}^{-2}$ ) and the average efficiency of PV modules ranged from 17.82 to $20.57 \%$. Power losses were up to $12.63 \mathrm{~W} \cdot \mathrm{m}^{-2}$, when the temperature of PV modules reached $53.5^{\circ} \mathrm{C}$. The results show that high PV module temperature causes noticeable power loss.
\end{abstract}

Keywords: renewable energy, solar power, PV module, temperature, efficiency.

\section{Introduction}

Climate change is one of the most important topics in recent years. Our civilization relies heavily on fossil fuels, as about $80 \%$ of primary energy comes from it [1;2]. Many countries and organizations in the world are setting their targets to increase renewable energy to save fossil resources, secure global energy demand and reduce greenhouse gas emissions [3-5].

Solar energy has been researched and used for hundreds of years, but the studies on the use of solar energy for power generation have begun relatively recently [6]. The two most popular technologies using solar energy are solar heating and photovoltaics (PV). Solar collectors are mostly used for heat collection and drying processes and their efficiency mostly depends on the absorber material $[7 ; 8]$. Photovoltaic systems, also known as solar power systems, are developing very fast, because of the efficiency increments and price reduction of PV modules [9]. In recent years, electricity production from PV systems has grown rapidly in the world [10]. However, compared to other countries, solar power usage in Latvia is very low. In terms regarding the use of solar energy for electricity production, Latvia ranks the last among the Baltic States and one of the last in the European Union [11].

Solar irradiance is the amount of power received from the Sun in the form of electromagnetic radiation. It is the main indicator of the amount of electricity that PV modules can produce [12]. It is a variable that is affected by geographical location (mostly latitude), climate zone and weather conditions [13; 14]. The efficiency of PV modules is one of the most important characteristics. It is determined by standard test conditions (STC) at $1000 \mathrm{~W} \cdot \mathrm{m}^{-2}$ of solar irradiance and PV module temperature of $25^{\circ} \mathrm{C}[15 ; 16]$. This means that temperature also has a very big impact on the performance of $\mathrm{PV}$ modules.

Excessive heat can significantly reduce the power of the PV modules. It may seem a surprise for many people, but PV module performance is affected negatively by temperature increases, and depending on the location of PV modules, high temperatures can reduce the power of PV modules even by $10-25 \%[17 ; 18]$. As the temperature of the PV modules increases, the voltage output reduces. As a result, the power of PV modules decreases $[19 ; 20]$. This is the reason, why it is important to research power losses of PV module overheating. 
The aim of the study is to determine and compare power losses from PV module overheating in several days with different weather conditions.

\section{Materials and methods}

In order to save money from electricity, in early 2019 on the farm Jasmini, which is located in Latvia, Rezekne municipality, Gaigalava parish, a solar PV system was set up on the roof of an agriculture machinery shed, which is located in the geographical $56^{\circ} 42^{\prime} 53.46^{\prime \prime} \mathrm{N}$ latitude and $27^{\circ} 3^{\prime} 0.68^{\prime \prime}$ E longitude. In total 22 polycrystalline, also known as multi-crystalline, RECOM Amur Leopard 270 PV modules with a total area of $35.79 \mathrm{~m}^{2}$ were installed. Each PV module is rated with a nominal power of $270 \mathrm{~W}$, which in total gives the nominal power of $5.94 \mathrm{~kW}$.

PV modules are installed parallel to the roof and are facing the south-west direction with the solar azimuth of $203^{\circ}$. The tilt angle of the PV modules is $30^{\circ}$. PV modules are not shaded and they are relatively high on the roof to achieve better cooling by the wind. This contributes to reduced power loss from PV module overheating. PV modules are connected to the inverter, which converts the DC electricity to AC electricity. The PV system is grid-tied, which means that the excess electricity is sent through the electricity meter to the main grid.

Fig. 1 shows the solar elevation angle, also known as the angular height of the Sun, during the period from sunrise to sunset in different months in the aforementioned geographical location. The red line in Fig. 1 shows the solar elevation angle, when it is directly facing PV modules.

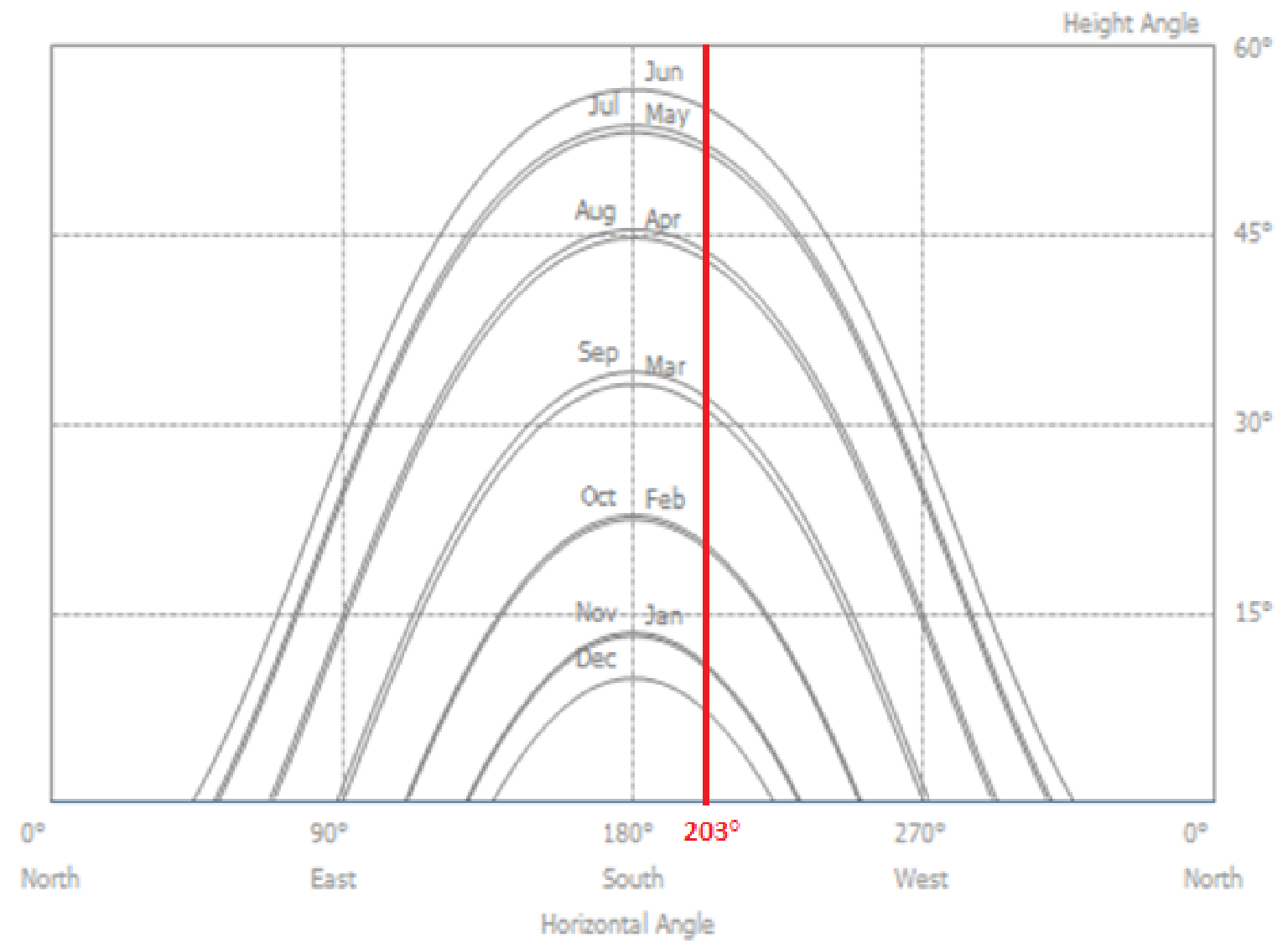

Fig. 1. Solar elevation angle in different months

PV modules are facing the south-west direction (azimuth of $203^{\circ}$ ). This means that theoretically the peak period of electricity production will not be at midday approximately from 12:00 to 13:15, when the sun is the highest, but about an hour later at approximately from 13:15 to 14:30.

Inputting the geographical location of the PV system in the solar PV system design software PV*SOL premium 2019 (R9), it was determined that in average it would be possible to produce 6616 $\mathrm{kWh}$ of electricity per year using this specific PV system. However, considering that the azimuth, tilt angle and other factors are not ideal, it was determined that the performance ratio of this specific PV 
system is $84.1 \%$. In other words, by using this PV system it is possible to generate $5564 \mathrm{kWh}$ of electricity per year on average. Furthermore, by using the software it was determined that from 10:00 to 18:00 PV modules approximately produce from $75 \%$ to $90 \%$ of all electricity. This is also the time period, when the farm usually has the highest electricity consumption.

The study to determine the power loss due to PV module overheating took place in spring of 2019. In total 4 temperature sensors were used in order to measure the temperature for the study. The first temperature sensor (T1) was used to determine the ambient temperature and 3 temperature sensors (T2, T3 and T4) were used to determine the temperature of PV modules. For data to be more objective, the PV module temperature sensors were mounted on different PV modules at different places and heights. The placement of the temperature sensors on the PV modules is shown in Fig. 2.

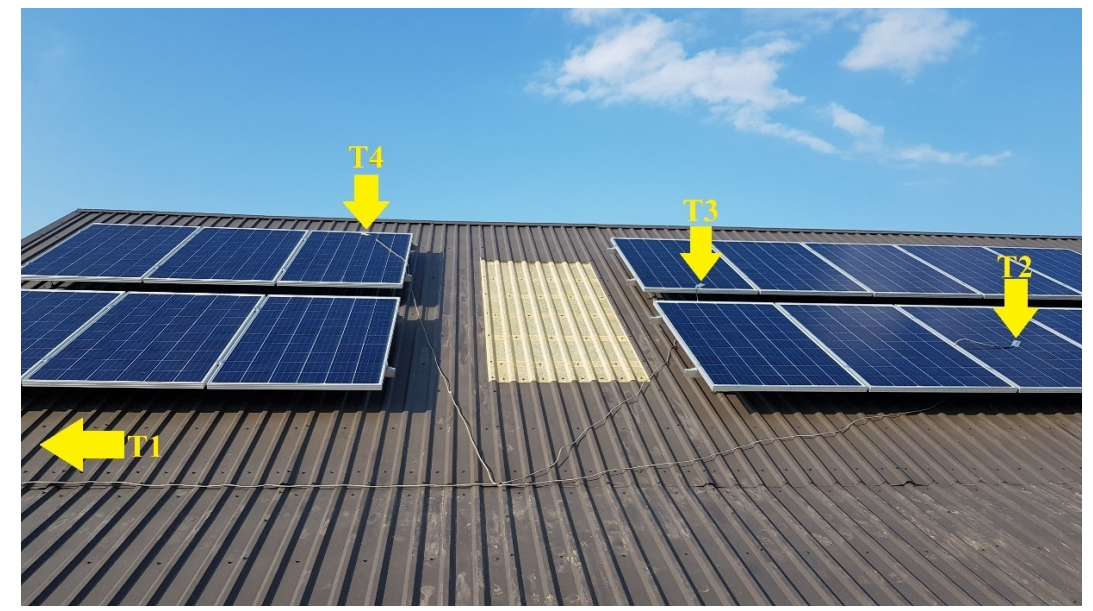

Fig. 2. Placement of temperature sensors on PV modules:

$\mathrm{T} 1$ - ambient temperature sensor; T2, T3, T4 - PV module temperature sensors

The temperature sensors are connected to the Baltic Instrument ltd LLU four-channel thermometer, whereas it is connected to the Baltic instrument ltd LLU data logger. Afterwards, during data processing, the average PV module temperature $\left(\mathrm{T}_{\text {avg }}\right)$ was calculated from all 3 PV module temperature sensors (T2, T3 and T4).

The solar irradiance was measured with a pyranometer CM3. It is connected to the Baltic instrument ltd LLU dual channel amplifier, whereas it is connected to the Baltic instrument ltd LLU data logger. The Baltic instrument ltd LLU data logger records temperature and solar irradiance every minute. The data logger, inverter and other devices are located inside the shed (Fig. 3).

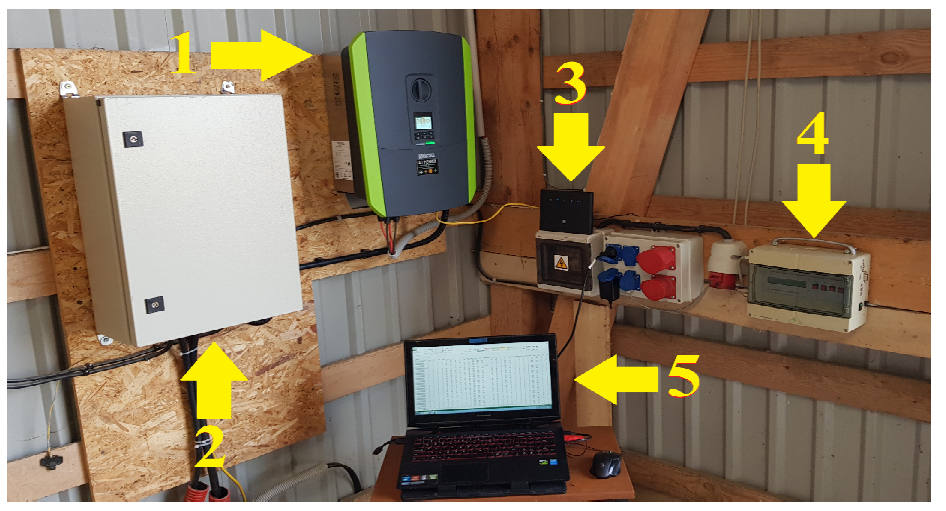

Fig. 3. Equipment inside the shed:

1 - inverter; 2 - electric panel; 3 - wireless router; 4 - data logger; 5 - laptop

The wireless router is connected to the inverter and uploads the data to the website www.pikosolar-portal.com (Fig. 4). In the website it is possible to see the produced electricity, power and other information of the PV system at any specific time range. The website www.suncalc.org (Fig. 5) was used to determine the position of the Sun. In the website it is possible to see the solar azimuth angle and solar elevation angle in any specific time, as well as the time of sunrise and sunset on any day. 


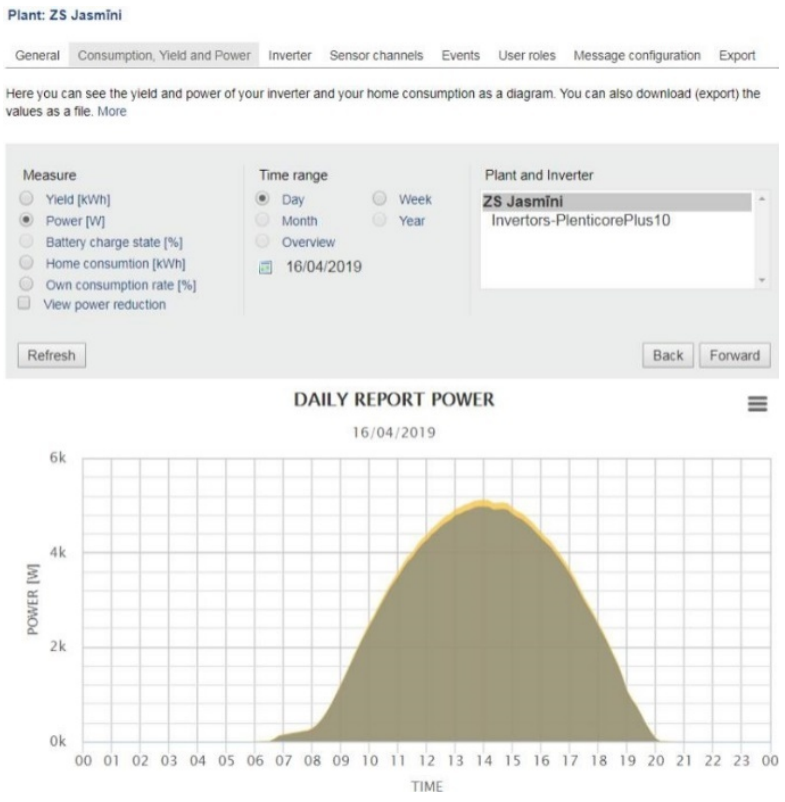

Fig. 4. Website www.piko-solar-portal.com

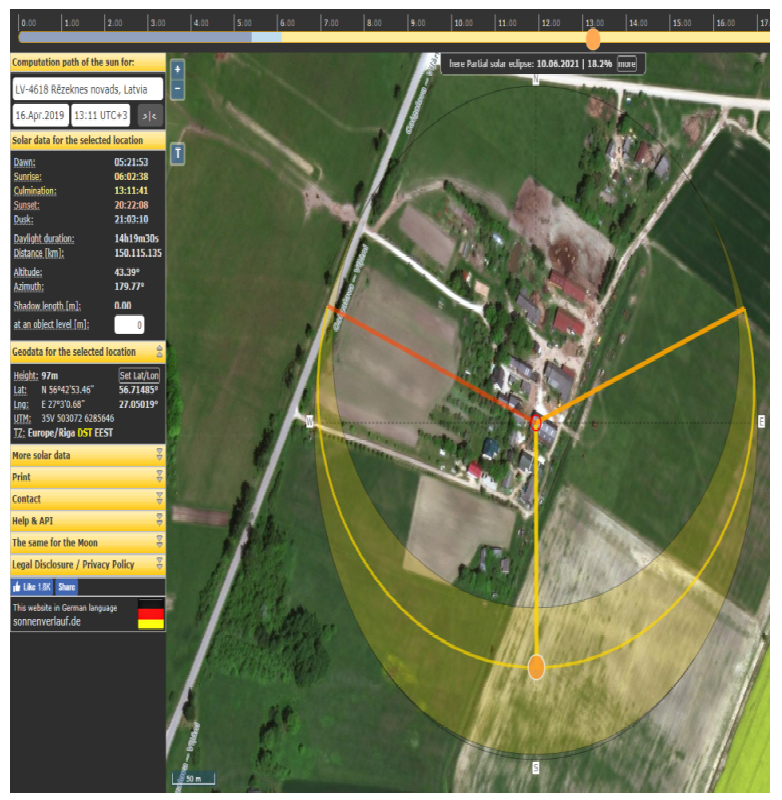

Fig. 5. Website www.suncalc.org

Measurements from sunrise to sunset were obtained from April to May, however, for better data analysis only measurements from 4 days were used: April 16, April 20, April 27 and May 8. These days were chosen, because they had relatively different weather conditions that affected the performance of PV modules.

The total area of PV modules is $35.79 \mathrm{~m}^{2}$ with the total nominal power of $5.94 \mathrm{~kW}$. However, for data to be more objective for further calculations, comparisons and results from the PV module area of $1 \mathrm{~m}^{2}$ were used. Dividing the total nominal power with the total area gives us the nominal power of 165.97 W for $1 \mathrm{~m}^{2}\left(165.97 \mathrm{~W} \cdot \mathrm{m}^{-2}\right)$ of PV modules.

According to the technical characteristics of RECOM Amur Leopard 270 PV modules, power loss from $\mathrm{PV}$ module overheating above $25^{\circ} \mathrm{C}$ is $0.4 \%$ per $1{ }^{\circ} \mathrm{C}\left(0.4 \% \cdot{ }^{\circ} \mathrm{C}\right)$. To calculate the power loss from PV module overheating formula (1) was used. After using formula (1), it is possible to calculate power losses in $\mathrm{W} \cdot \mathrm{m}^{-2}$.

$$
P_{L}=\left(T_{P V}-25\right) 0.4,
$$

where $P_{L}$ - power losses, $\%$;

$T_{P V}-\mathrm{PV}$ module temperature, ${ }^{\circ} \mathrm{C}$.

\section{Results and discussion}

The first measurements were taken on April 16 from 6:06 to 20:19. The weather was sunny and clear throughout the day. The ambient temperature (T1) ranged from $1.5^{\circ} \mathrm{C}$ to $18.2^{\circ} \mathrm{C}$, but on average it was $12.4^{\circ} \mathrm{C}$ and PV modules overheated up to $40.8^{\circ} \mathrm{C}$. The highest solar elevation angle was $43.39^{\circ}$ at 13:11. Also at this time the highest solar irradiance $691.2 \mathrm{~W} \cdot \mathrm{m}^{-2}$ was observed. Measurements of the solar elevation angle, irradiance and temperature on April 16 are shown graphically in Fig. 6.

The second measurements were taken on April 20 from 5:55 to 20:28. The weather throughout the day was very unstable due to mostly cloudy skies with only occasional sunlight. The ambient temperature ranged from $3.0^{\circ} \mathrm{C}$ to $17.8^{\circ} \mathrm{C}$, but on average it was $12.1^{\circ} \mathrm{C}$ and $\mathrm{PV}$ modules overheated up to $39.5^{\circ} \mathrm{C}$. The highest solar elevation angle was $44.79^{\circ}$ at $13: 10$, but the highest solar irradiance was $824.5 \mathrm{~W} \cdot \mathrm{m}^{-2}$ at 13:40. Measurements of the solar elevation angle, irradiance and temperature on April 20 are shown graphically in Fig. 7.

The third measurements were taken on April 27 from 5:38 to 20:42. The weather was sunny and clear until noon, but later it became cloudy with only occasional sunlight. The ambient temperature ranged from $6.8^{\circ} \mathrm{C}$ to $28.3{ }^{\circ} \mathrm{C}$, but on average it was $20.4^{\circ} \mathrm{C}$ and $\mathrm{PV}$ modules overheated up to $53.5^{\circ} \mathrm{C}$. The highest solar elevation angle was $47.11^{\circ}$ at $13: 09$. Also at this time the highest solar 
irradiance $703.5 \mathrm{~W} \cdot \mathrm{m}^{-2}$ was observed. Measurements of the solar elevation angle, irradiance and temperature on April 27 are shown graphically in Fig. 8.

The fourth measurements were taken on May 8 from 5:13 to 21:05. The weather throughout the day was relatively cold, but mostly sunny. The ambient temperature ranged from $0.1{ }^{\circ} \mathrm{C}$ to $16.8^{\circ} \mathrm{C}$, but on average it was $10.4{ }^{\circ} \mathrm{C}$ and $\mathrm{PV}$ modules overheated up to $44.8^{\circ} \mathrm{C}$. The highest solar elevation angle was $50.36^{\circ}$ at $13: 08$, but the highest solar irradiance was $816.2 \mathrm{~W} \cdot \mathrm{m}^{-2}$ at $13: 30$. Measurements of the solar elevation angle, irradiance and temperature on May 8 are shown graphically in Fig. 9.

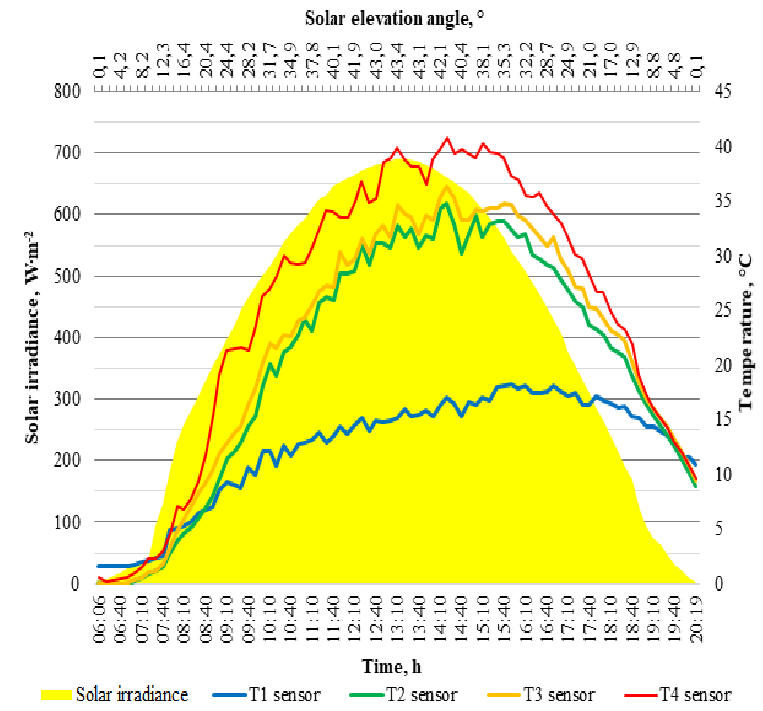

Fig. 6. Solar elevation angle, irradiance and temperature on April 16

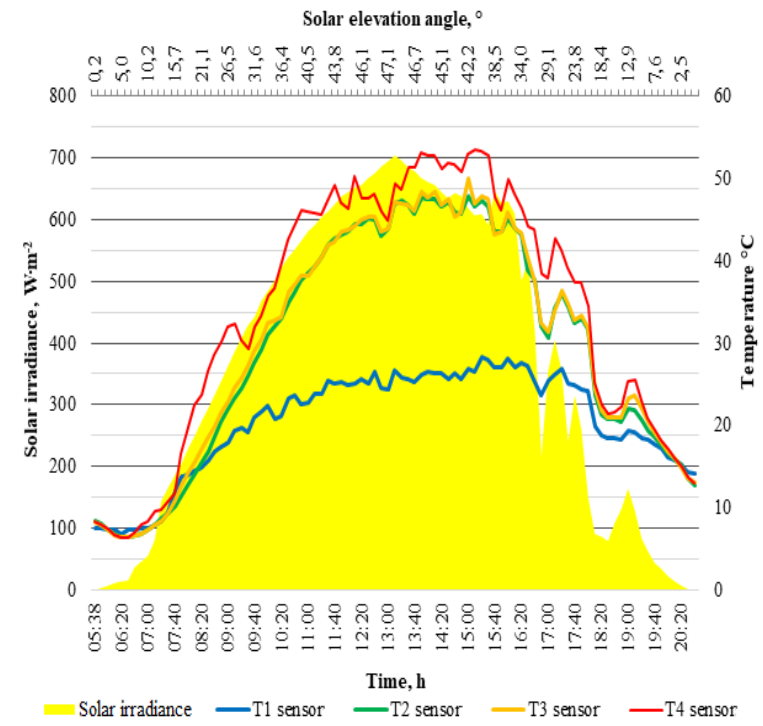

Fig. 8. Solar elevation angle, irradiance and temperature on April 27

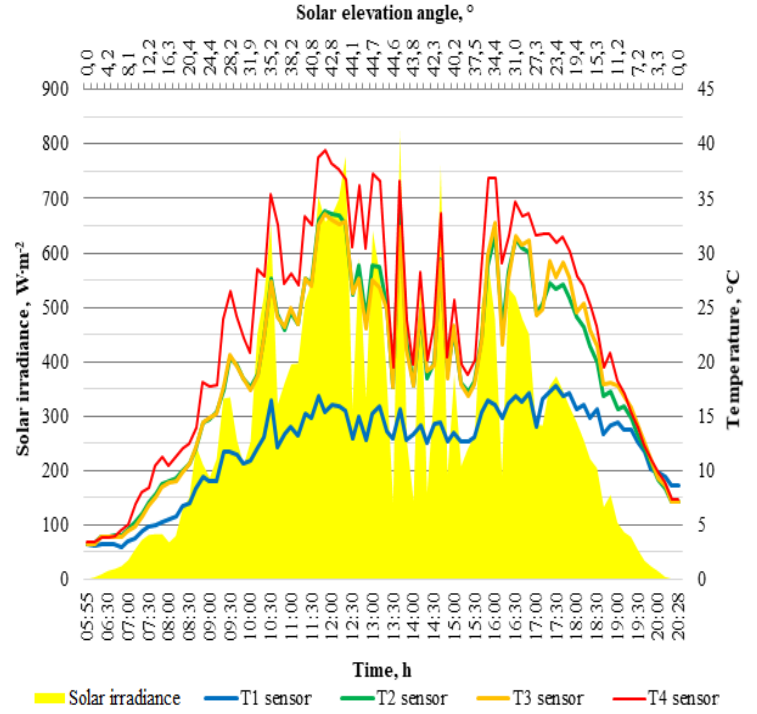

Fig. 7. Solar elevation angle, irradiance and temperature on April 20

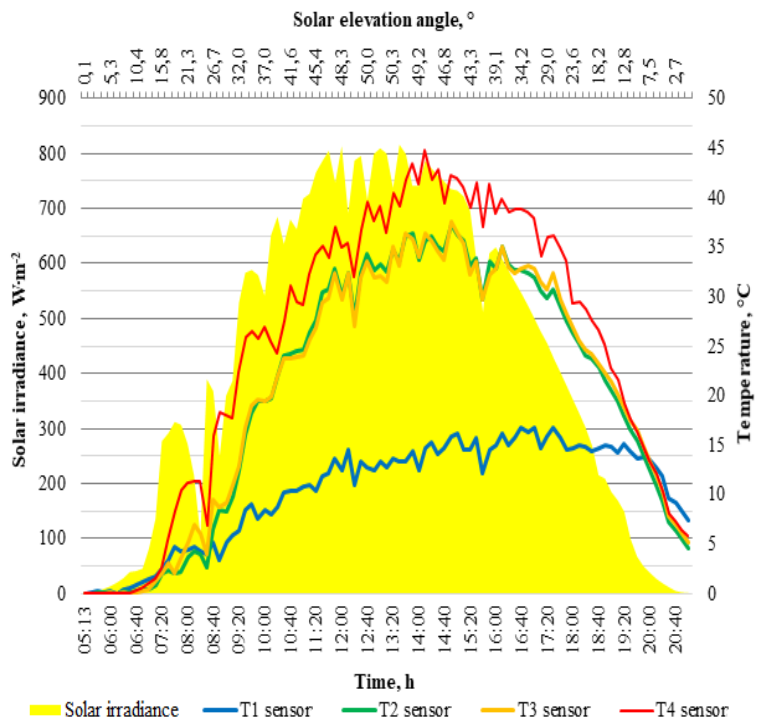

Fig. 9. Solar elevation angle, irradiance and temperature on May 8

On April 16, in total PV modules produced $37.9 \mathrm{kWh}$ of electricity or $1059 \mathrm{Wh} \cdot \mathrm{m}^{-2}$. PV power reached $142.74 \mathrm{~W} \cdot \mathrm{m}^{-2}$ at $14: 20$, when the Sun was directly facing PV modules at the solar azimuth angle of $202.7^{\circ}$. Power losses from PV module overheating were observed from 10:50 to 17:50, when the average temperature $\left(T_{\text {avg }}\right)$ of PV modules exceeded the STC temperature of $25^{\circ} \mathrm{C}$. Power losses from PV module overheating reached $7.02 \mathrm{~W} \cdot \mathrm{m}^{-2}$. Measurements of the solar azimuth angle, PV module average temperature, power and power loss on April 16 are shown graphically in Fig. 10. 
On April 20, in total PV modules produced $26.37 \mathrm{kWh}$ of electricity or $737 \mathrm{Wh} \cdot \mathrm{m}^{-2}$. PV power reached $154.28 \mathrm{~W} \cdot \mathrm{m}^{-2}$ at $13: 40$, when the solar azimuth angle was $190.1^{\circ}$. Power losses from PV module overheating were occasional and were up to $5.72 \mathrm{~W} \cdot \mathrm{m}^{-2}$. Measurements of the solar azimuth angle, PV module average temperature, power and power loss on April 20 are shown graphically in Fig. 11.

On April 27, in total PV modules produced $33.51 \mathrm{kWh}$ of electricity or $936 \mathrm{Wh} \cdot \mathrm{m}^{-2}$. PV power reached $128.86 \mathrm{~W} \cdot \mathrm{m}^{-2}$ at $13: 40$, when the solar azimuth angle was $190.8^{\circ}$. Power losses from PV module overheating were observed from 9:00 to 18:00. Power losses from PV module overheating reached $12.63 \mathrm{~W} \cdot \mathrm{m}^{-2}$. Measurements of the solar azimuth angle, $\mathrm{PV}$ module average temperature, power and power loss on April 27 are shown graphically in Fig. 12.

On May 8, in total PV modules produced $41.38 \mathrm{kWh}$ of electricity or $1156 \mathrm{Wh} \cdot \mathrm{m}^{-2}$. PV power reached $149.37 \mathrm{~W} \cdot \mathrm{m}^{-2}$ at $13: 40$, when the solar azimuth angle was $191.8^{\circ}$. Power losses from PV module overheating were observed from 10:30 to 18:30. Power losses from PV module overheating reached $8.34 \mathrm{~W} \cdot \mathrm{m}^{-2}$. Measurements of the solar azimuth angle, PV module average temperature, power and power loss on May 8 are shown graphically in Fig. 13.

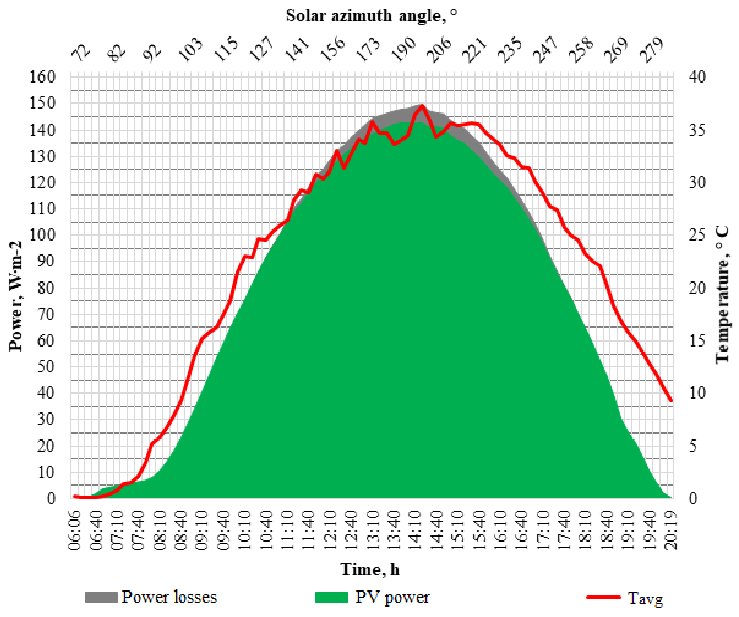

Fig. 10. Solar azimuth angle, $\mathrm{PV}$ power and power losses on April 16

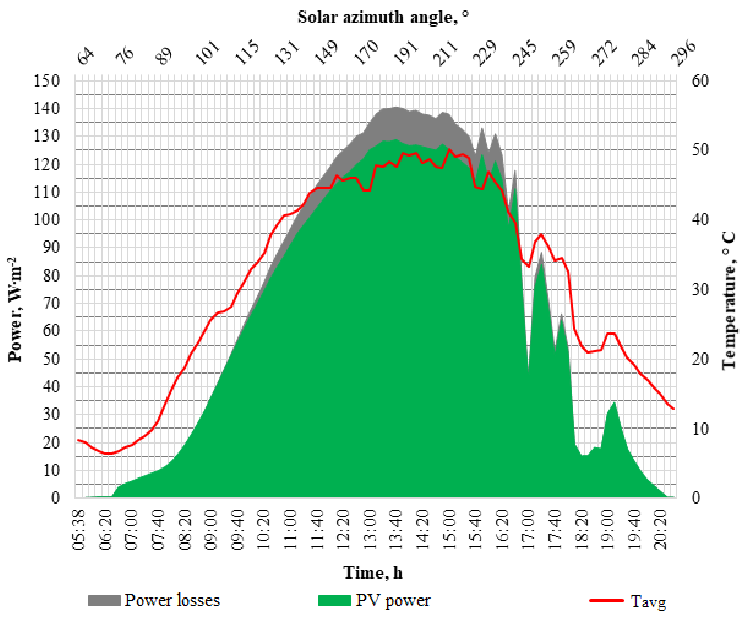

Fig. 12. Solar azimuth angle, $P V$ power and power losses on April 27

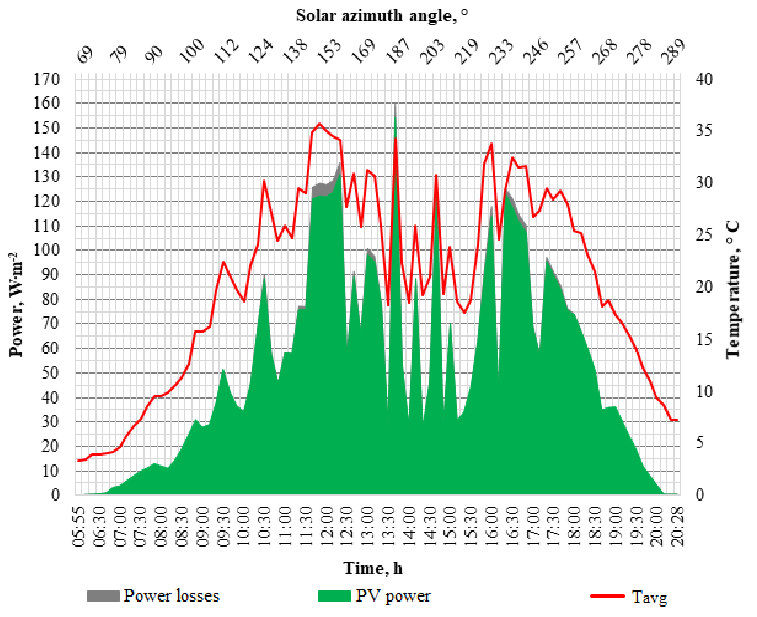

Fig. 11. Solar azimuth angle, $P V$ power and power losses on April 20

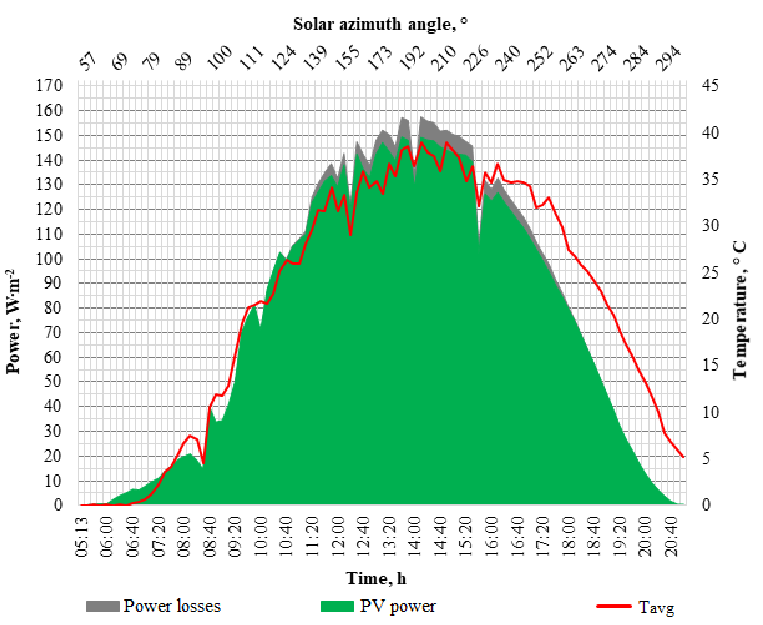

Fig. 13. Solar azimuth angle, $P V$ power and power losses on May 8

Analysing and comparing the graphs in Fig. 6-13, it is clear that the different weather conditions had a very big impact on the performance of the PV modules. All obtained measurements from sunrise to sunset from Fig. 6-13 are summarized in Table 1.

However, the time of sunrise and sunset was different on each day. As a result, the daylight duration was also different on each day. To achieve more objective results the obtained data were 
analysed from 10:00 to 18:00. This period of time was chosen, because PV modules produce approximately from 75 to $90 \%$ of all electricity at this time and the farm usually has the highest electricity consumption.

Table 1

Summary of obtained measurements

\begin{tabular}{|c|c|c|c|c|}
\hline \multirow{2}{*}{ Measurement } & \multicolumn{4}{|c|}{ Day of obtained measurements } \\
\cline { 2 - 5 } & April 16 & April 20 & April 27 & May 8 \\
\hline Sunrise time, $\mathrm{h}$ & $6: 06$ & $5: 55$ & $5: 38$ & $5: 13$ \\
\hline Sunset time, $\mathrm{h}$ & $20: 19$ & $20: 28$ & $20: 42$ & $21: 05$ \\
\hline Daylight duration & $14 \mathrm{~h} 13 \mathrm{~min}$ & $14 \mathrm{~h} \mathrm{33}$ min & $15 \mathrm{~h} 4 \mathrm{~min}$ & $15 \mathrm{~h} 52 \mathrm{~min}$ \\
\hline Lowest ambient temperature, $^{\circ} \mathrm{C}$ & 1.5 & 3.0 & 6.8 & 0 \\
\hline Highest ambient temperature, $^{\circ} \mathrm{C}$ & 18.2 & 17.8 & 28.3 & 16.8 \\
\hline Highest PV module temperature, $^{\circ} \mathrm{C}$ & 40.8 & 39.5 & 53.5 & 44.8 \\
\hline Highest solar elevation angle, $^{\mathbf{o}}$ & 43.39 & 44.79 & 47.11 & 50.36 \\
\hline${\text { Highest solar irradiance, } \mathrm{W} \cdot \mathrm{m}^{-2}}^{-2}$ & 691.2 & 824.5 & 703.5 & 816.2 \\
\hline Highest PV power, $\mathrm{W} \cdot \mathrm{m}^{-2}$ & 142.74 & 154.28 & 128.86 & 149.37 \\
\hline Highest power losses, $\mathrm{W} \cdot \mathrm{m}^{-2}$ & 7.02 & 5.72 & 12.63 & 8.34 \\
\hline Total produced electricity, $\mathrm{kWh}^{-2}$ & 37.9 & 26.37 & 33.51 & 41.38 \\
\hline Produced electricity, $\mathrm{Wh} \cdot \mathrm{m}^{-2}$ & 1059 & 737 & 936 & 1156 \\
\hline
\end{tabular}

One of the most important parameters of PV modules is PV efficiency. It is a measurement used to show how much solar irradiance PV modules can convert into power [20]. To calculate the average efficiency of PV modules from 10:00 to 18:00, formula (2) was used.

$$
\eta=\frac{P}{G} 100 \%,
$$

where $\eta$-efficiency of PV modules, \%;

$P$ - PV power, $\mathrm{W} \cdot \mathrm{m}^{-2}$

$G-$ solar irradiance, $\mathrm{W} \cdot \mathrm{m}^{-2}$.

After all necessary calculations, the most important results from 10:00 to 18:00 are summarized in Table 2.

Table 2

\section{Summary of results from 10:00 to 18:00}

\begin{tabular}{|c|c|c|c|c|}
\hline \multirow{2}{*}{ Parameter } & \multicolumn{4}{|c|}{ Day of obtained measurements } \\
\cline { 2 - 5 } & April 16 & April 20 & April 27 & May 8 \\
\hline Average solar irradiance, $\mathrm{W} \cdot \mathrm{m}^{-2}$ & 567.96 & 432.74 & 560.81 & 665.37 \\
\hline Average ambient temperature, ${ }^{\circ} \mathrm{C}$ & 15.49 & 14.68 & 25.35 & 13.50 \\
\hline Average PV module temperature, ${ }^{\circ} \mathrm{C}$ & 31.07 & 27.03 & 43.07 & 32.85 \\
\hline Average power losses, $\%$ & 2.43 & 0.81 & 7.23 & 3.14 \\
\hline Average power losses, $\mathrm{W} \cdot \mathrm{m}^{-2}$ & 3.20 & 1.25 & 7.98 & 4.15 \\
\hline Average PV power, $\mathrm{W} \cdot \mathrm{m}^{-2}$ & 116.82 & 77.13 & 103.51 & 122.51 \\
\hline Average efficiency of PV modules, \% & 20.57 & 17.82 & 18.46 & 18.41 \\
\hline
\end{tabular}

Mathcad and Mathlab mathematical packages were used for data processing and mathematical modelling. Nonlinear multivariable regression (3) was observed. The coefficient of determination $\mathrm{R}^{2}$ is also calculated to describe the accordance of the theoretical relationship to obtained data.

$$
P=a_{0}+a_{1} G+a_{2} G^{2}+a_{3} T_{P V}+a_{4} T_{P V}{ }^{2}+a_{5} G T_{P V},
$$

where $P-\mathrm{PV}$ power, $\mathrm{W} \cdot \mathrm{m}^{-2}$;

$a_{i}$ - constant that describes the effect of solar irradiance and PV module temperature on PV power;

$G$ - solar irradiance, $\mathrm{W} \cdot \mathrm{m}^{-2}$;

$T_{P V}-\mathrm{PV}$ module temperature, ${ }^{\circ} \mathrm{C}$. 
After accomplishing all necessary calculations, the equation (4) is received.

$$
P=-48.5+0.032 G+4.410^{-5} G^{2}+4.96 T_{P V}-0.03 T_{P V}{ }^{2}+610^{-4} G T_{P V} .
$$

The coefficient of determination $R^{2}=0.98$ shows a strong accordance of the theoretical relationship to obtained data. The graphical interpretation of the PV power, PV module temperature and solar irradiance is shown in Fig. 14.

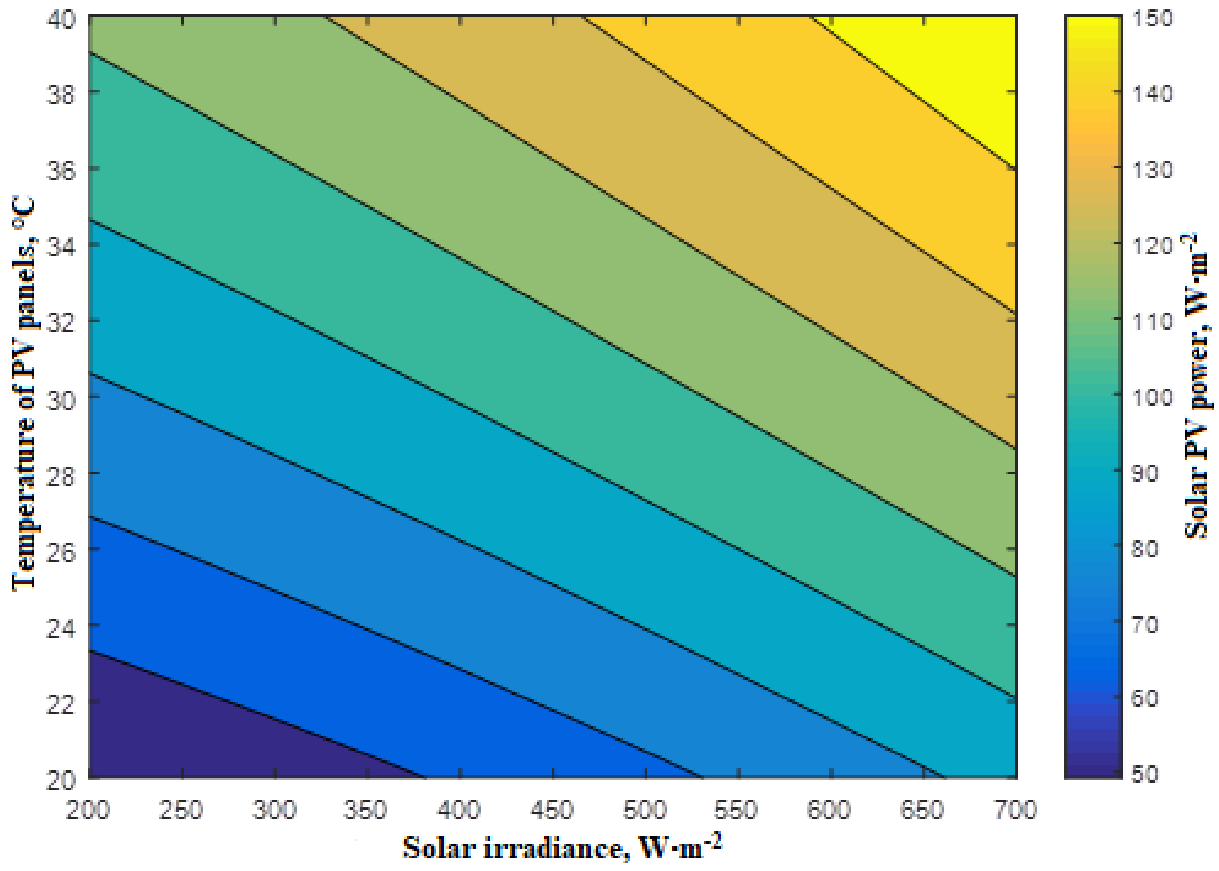

Fig. 14. Graphical interpretation of PV power, PV module temperature and solar irradiance

In equation (4) the part $-0.03 T_{P V}$ shows that, as the PV module temperature increases, the PV power begins to decrease, and as a result, the efficiency of PV modules begins to decline.

\section{Conclusions}

1. The highest solar irradiance on a clear day is usually, when the solar elevation angle is the highest, but the most PV power is, when the Sun is directly facing PV modules.

2. The average efficiency of PV modules from 10:00 to 18:00 was $18.82 \%$. The highest efficiency of PV modules $20.57 \%$ was on April 16, when the weather throughout the day was sunny and clear with the average solar irradiance of $567.96 \mathrm{~W} \cdot \mathrm{m}^{-2}$. The lowest efficiency of PV modules $17.82 \%$ was on April 20, when the weather throughout the day was cloudy with only occasional sunlight and the average solar irradiance was $432.74 \mathrm{~W} \cdot \mathrm{m}^{-2}$.

3. High temperature causes power loss. On April $27 \mathrm{PV}$ modules overheated up to $53.5^{\circ} \mathrm{C}$. As a result, power loss from PV module overheating was up to $12.63 \mathrm{~W} \cdot \mathrm{m}^{-2}$, but on average from 10:00 to 18:00 it was $7.98 \mathrm{~W} \cdot \mathrm{m}^{-2}$. Comparing the results of April 16 and April 27, when the average solar irradiance was almost the same, but the PV module temperature was $12{ }^{\circ} \mathrm{C}$ higher on April 27, the PV module efficiency on April 16 was $2.11 \%$ higher.

4. High solar irradiance and low ambient temperature are ideal factors for PV modules. The highest average PV power from 10:00 to 18:00 was $122.51 \mathrm{~W} \cdot \mathrm{m}^{-2}$ on May 8 , when the average solar irradiance was $665.37 \mathrm{~W} \cdot \mathrm{m}^{-2}$ and the average temperature of PV modules was $32.85^{\circ} \mathrm{C}$.

\section{References}

[1] Harjanne A., Korhonen J.M. Abandoning the concept of renewable energy. Energy Policy, vol. 127, 2019, pp. 330-340.

[2] Gautam P., Kumar S., Lokhandwala S. Energy-aware intelligence in megacities. In Current Developments in Biotechnology and Bioengineering. Elsevier, 2019, pp. 211-238. 
[3] Ellabban O., Abu-Rub H., Blaabjerg F. Renewable energy resources: Current status, future prospects and their enabling technology. Renewable and Sustainable Energy Reviews, vol. 39, pp. 748-764.

[4] Gielen D., Boshell F., Saygin D. etc. The role of renewable energy in the global energy transformation. Energy Strategy Reviews, vol. 24, 2019, pp. 38-50.

[5] Morgan E.A., Nalau J., Mackey B. Assessing the alignment of national-level adaptation plans to the Paris Agreement. Environmental Science \& Policy, vol. 93, 2019, pp. 208-220.

[6] Bayrak F., Abu-Hamdeh N., Alnefaie K.A. etc. A review on energy analysis of solar electricity production. Renewable and Sustainable Energy Reviews, vol. 74, 2017, pp. 755-770.

[7] Aboltins A., Palabinskis J. New types of air heating solar collectors and their use in drying agricultural products. Agronomy Research, vol. 11(2), 2013, pp. 267-274.

[8] Ruskis G., Aboltins A., Palabinskis J. Different material investigations in air heating flat-plate solar collector. Proceedings of the 10th International Scientific Conference „Engineering for Rural Development”, May 26-27, 2011, Jelgava, Latvia, pp. 330-335.

[9] Kavlak G., McNerney J., Trancik J.E. Evaluating the causes of cost reduction in photovoltaic modules. Energy Policy, vol. 123, 2018, pp. 700-710.

[10] Ravikumar D., Wender B., Seager T.P., etc. A climate rationale for research and development on photovoltaics manufacture. Applied Energy, vol. 189, 2017, pp. 245-256.

[11] Renewable energy statistics 2019. [online] [19.03.2020]. Available at: https://www.irena.org//media/Files/IRENA/Agency/Publication/2019/Jul/IRENA_Renewable_energy_statistics_2019.pd

[12]Lee J., Wang W., Harrou F. etc. Reliable solar irradiance prediction using ensemble learningbased models: A comparative study. Energy Conversion and Management, vol. 208, 2020, paper No. 112582.

[13]Zambrano A.F., Giraldo L.F. Solar irradiance forecasting models without on-site training measurements. Renewable Energy, vol. 152, 2020, pp. 557-566.

[14] Babar B., Luppino L.T., Boström T. etc. Random forest regression for improved mapping of solar irradiance at high latitudes. Solar Energy, 2020, vol. 198, pp. 81-92.

[15] Karthikeyan V., Sirisamphanwong C., Sukchai S. etc. Reducing PV module temperature with radiation based PV module incorporating composite phase change material. Journal of Energy Storage, vol. 29, 2020, paper No. 101346.

[16] Humada A.M., Darweesh S.Y., Mohammed K.G. etc. Modeling of PV system and parameter extraction based on experimental data: Review and investigation. Solar Energy, vol. 199, 2020, pp. 742-760.

[17] Yadav K., Kumar B., Swaroop D. Mitigation of Mismatch Power Losses of PV Array under Partial Shading Condition using novel Odd Even Configuration. Energy Reports, vol. 6, 2020, pp. 427-437.

[18] Shen L., Li Z., Ma T. Analysis of the power loss and quantification of the energy distribution in PV module. Applied Energy, vol. 260, 2020, page No. 114333.

[19] Ayeng'o S.P., Axelsen H., Haberschusz, D. etc. A model for direct-coupled PV systems with batteries depending on solar radiation, temperature and number of serial connected PV cells. Solar Energy, vol. 183, pp. 120-131.

[20] Ali H.M. Recent advancements in PV cooling and efficiency enhancement integrating phase change materials based systems-A comprehensive review. Solar Energy, vol. 197, pp. 163-198. 